\title{
照射並びに特殊治療後の顎・顔面における 高度半側萎縮の形成手術
}

$\begin{array}{lllll}\text { 高橋 } & \text { 良・飯田 } & \text { 太 } \\ \text { 鈴木 孝 } & \text { 尚・金 谷充 招 }\end{array}$

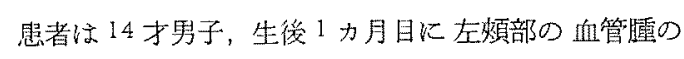
ため、ドライアイスによる治痖を受けたが，当時その部

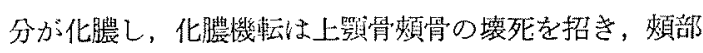

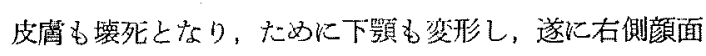
の高度の萎絔をきたすに至つた。

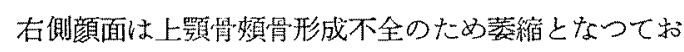

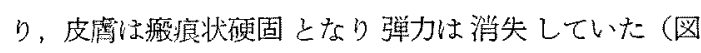
1).

この種の半側曈縮の形成手術には自家硬組織，Alloplasty, Fat dermal graft 等の皮下搜入も考えられる

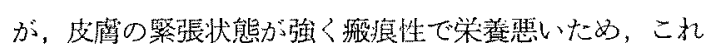
等の方法は適当ではない，そこで背部に巨大な Tubed pedicle flap を作成した（四 2)，更にこの flap を jump flap として石眼䆚外側部に移動し，更に他端をU 字状に下顎外側部に移植した（图 3)。この生着を待つ てから舅根部改び眼製下部の部分は Tube 内の余分の 脂肪を除去して，縫台を行つた（园 4)。この flapに

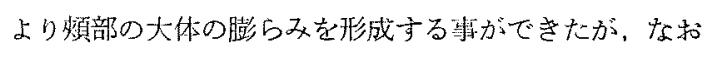

更に外率形態及びロ刍部の微細な形成が要求されるた め，側胸部に作製した細い、Tubed pedicle flapをこれ に利用した（図 5)。

現在なお Cosmetic に今後治すべき所が多少牫つて いるが，Reconstruction としてはほほ目的を達した (図 6).

Tubed pedicle flap を用いる㖽顔面の Reconistructive surgery はその立体的な形態上長期間を要するる のであるが，補塂形成すべき部分がかなり大きい場合， 㕛表面皮境が利用できない場合等には推罢し得る手術法 と腎われ。

顎顔面の顕諸な茲縮形成不全や欠損，例えば副鼻腔癌 全㧩後や特発性鼻壊直の治癒後の欠損又レ線照射や本例

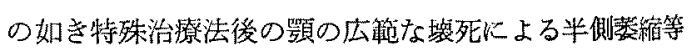
の際に执ける組織欠損のための登間の補填には厚くて大 きい又は蹴打ちされた flap が要求されるのでこの種の 颉顔面の Reconstructive surgery には，大きいTubed pedicle flap を用いるのがよいと思う。 

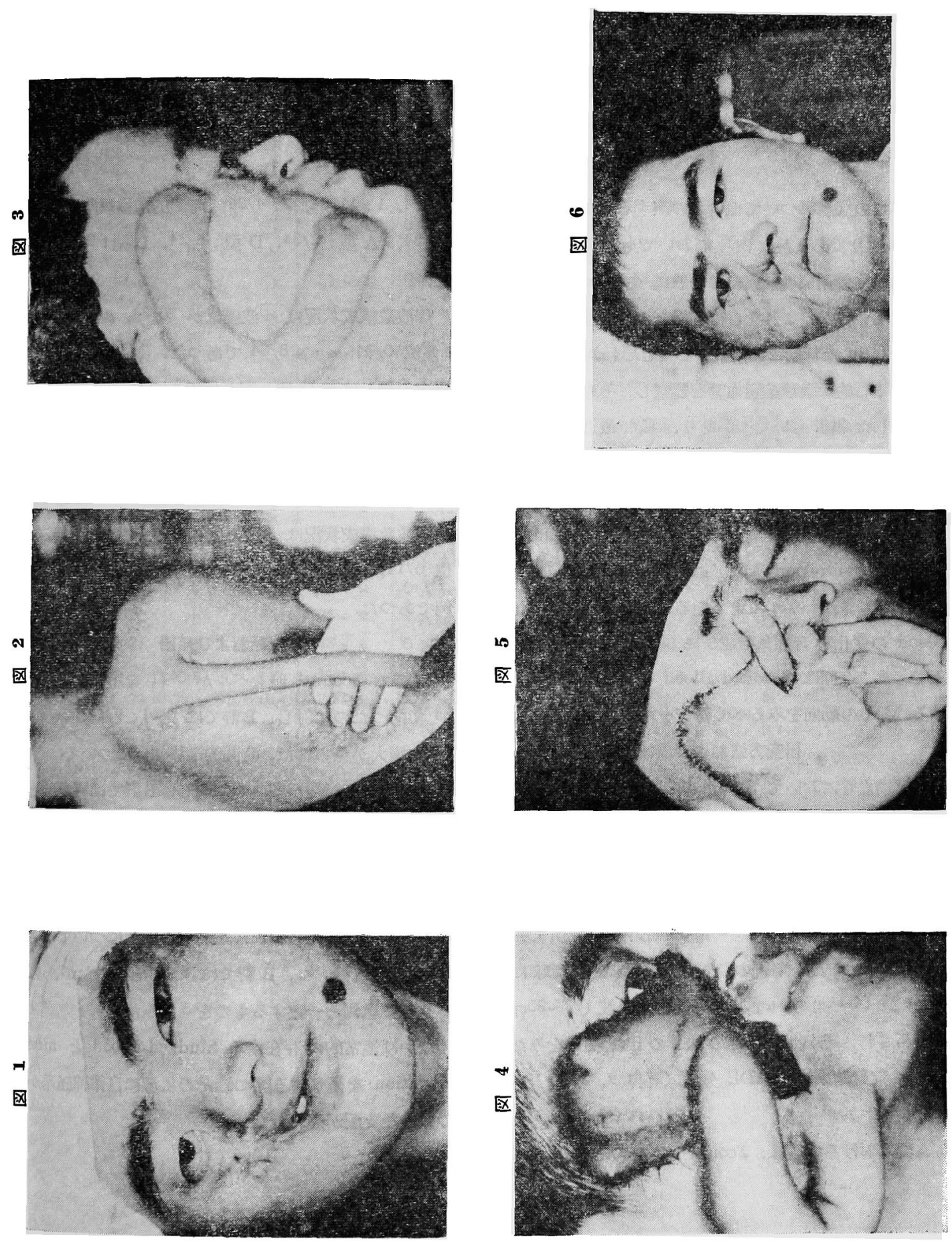